\title{
The Affect of Images: Signorelli, Morto da Feltre, and Moving Creativity in the Art of Grotesques c. 1500
}

\author{
Maria Fabricius Hansen, \\ University of Copenhagen
}

\begin{abstract}
This article discusses the affect of images, focusing on a notion prevalent in the art and theory of the fifteenth and sixteenth centuries: that movement in paintings corresponds with (emotional) movement in the spectator and with the imagination or creativity of the artist. It addresses the work of Signorelli, Morto da Feltre, Pinturicchio, and Sodoma (c. 1500) and, in particular, their grotesques. This art form, which became remarkably prolific in fresco decorations of sixteenth century villas and palaces, was appreciated as a figuration of movement, understood both literally, in terms of the grotesques' formal qualities of figure serpentinate (spiraling, turning shapes); and metaphorically, as generated by the turbulent imagination of the artist. Through their marginality, the grotesques constituted a distinct field within the visual culture of their time, investigating metamorphosis and monstrosity. Here, the creative power of the artist could be explored, and the boundaries between image and spectator challenged.
\end{abstract}

Keywords: art and nature, artistic self-representation, contrapposto, imagination, monstrosity, movement, perversion

Around 1500, in the main cultural centers of Italy, the preoccupation with the question of the life and death of images was remarkable: on one hand, a fascination with images that appear to be alive and which affect the viewer as if they were real human beings; on the other hand, an awareness of images as art, of images as fixed and immovable representations, as a motionless artificiality, bound to their medium.

\section{DEAD OR ALIVE?}

Contemporary theorists of art maintained that the imitation of nature was the primary goal of art, praising works of art for their life-likeness-frequently using the old topos that they only lacked breath to be alive. ${ }^{1}$ From the late fifteenth century and after, these prescriptions went hand-in-hand with the new artistic practice of making studies from life and, increasingly, with an emphasis on the movement of figures through all possible variations of contrapposto. This might prompt the conclusion that Renaissance artists simply strove to make their painting indistinguishable from real life. Yet, the approach to the being and non-being of images was more complex than this: the idea that movement equals life and that movement in art will move the spectator, was related with the idea of movement in art as synonymous with artistic invention and creativity, a precondition for creating life-like art. At the same time, however, there was a cautious attitude towards movement, based on the conviction that the imagination of the artist should not manifest itself too strongly (Summers, 1977, pp. 336-361).

Here, we shall concentrate on a specific field within the visual culture of the period, the so-called grotesques that were immensely popular as fresco decoration for walls and ceilings in the palaces and villas of the social elite (Figure 1). ${ }^{2}$ The grotesque is an imagery constituted by hybrid monstrosity and metamorphosis, embodying an obsession with movement and the affective potential of art (Figure 2). ${ }^{3}$ The grotesques illustrate how the notion of movement in painting was related with the movement or affect of the spectator, how movement was understood as corresponding to the artistic imagination and the creativity of the artist and, in particular, the ambivalent attitude toward this imagination and creativity in the period around 1500 .

Addressing the problems and possibilities of life-like images, Luca Signorelli's famous representation of the Last Judgment in the Cappella Nuova of the Cathedral of Orvieto (1499-1504) is a remarkable manifestation of this consciousness of art as both moving and static (Figure 3). In the chapel, 

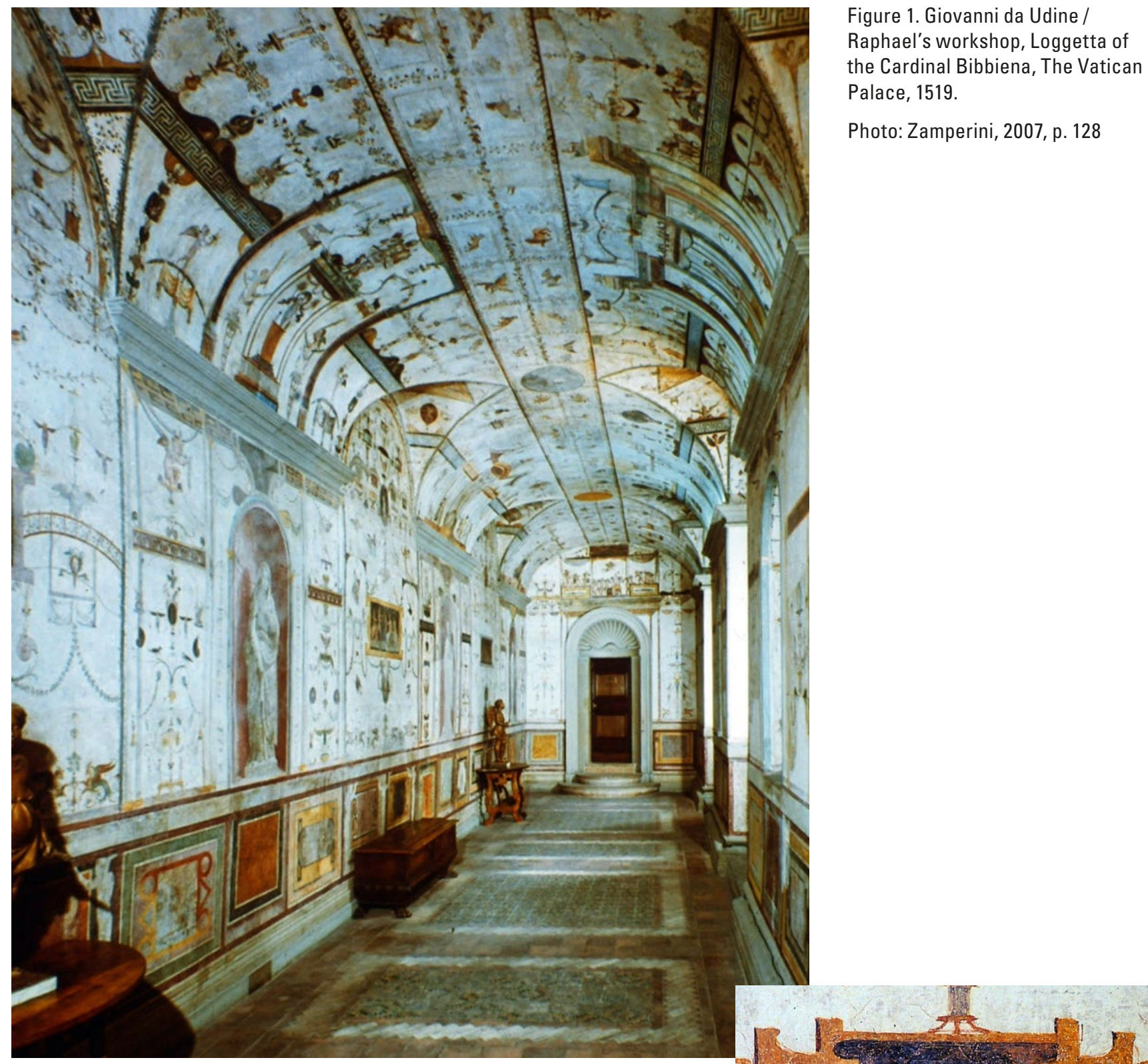

Raphael's workshop, Loggetta of

Palace, 1519.

Photo: Zamperini, 2007, p. 128

Signorelli situated the historia of The End of Time above a zone of elaborate, monstrous grotesques with framed portraits of ancient poets. In one case, such a figure is represented as transgressing his frame and reacting as if startled by the painting that surrounds him (Figure 4). ${ }^{4}$ Apparently, the monstrous grotesques that transform from one creature into another through dynamic, spiraling movements are highly affecting to this figure-a figure which assumes a stand-in position for the spectator in the overall spatial composition of the chapel. This play with levels of reality in the chapel's fresco decoration is in line with a century long tradition, where for instance small representations of prophets in the Old Testament would be included as formal and conceptual framing of a New Testament subject. Such figures often confront the viewer directly by transgressing the space in which they are represented, for instance through protrusions of their

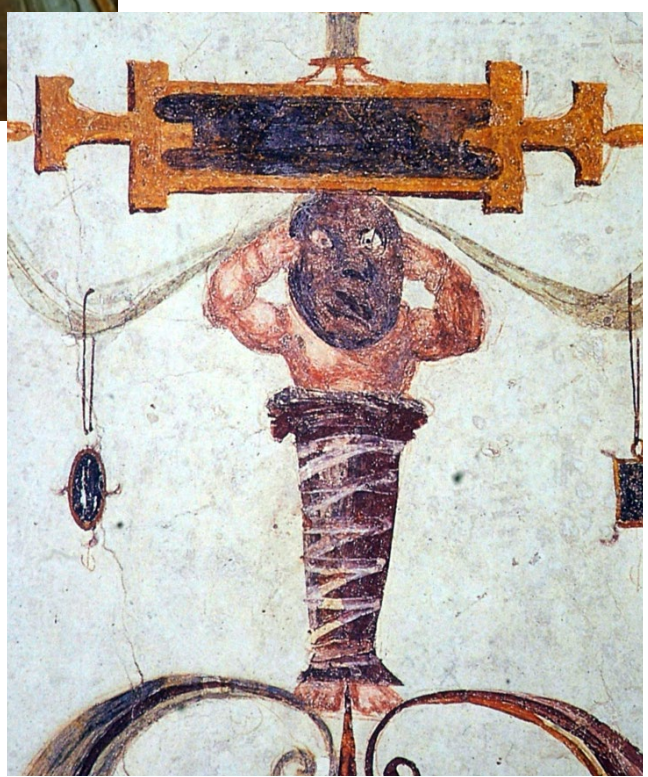

Figure 2: Giovanni da Udine /Raphael's workshop, detail from the Loggetta of the Cardinal Bibbiena, The Vatican Palace, 1519.

Photo: Dacos \& Furlan 1987, p. 54 


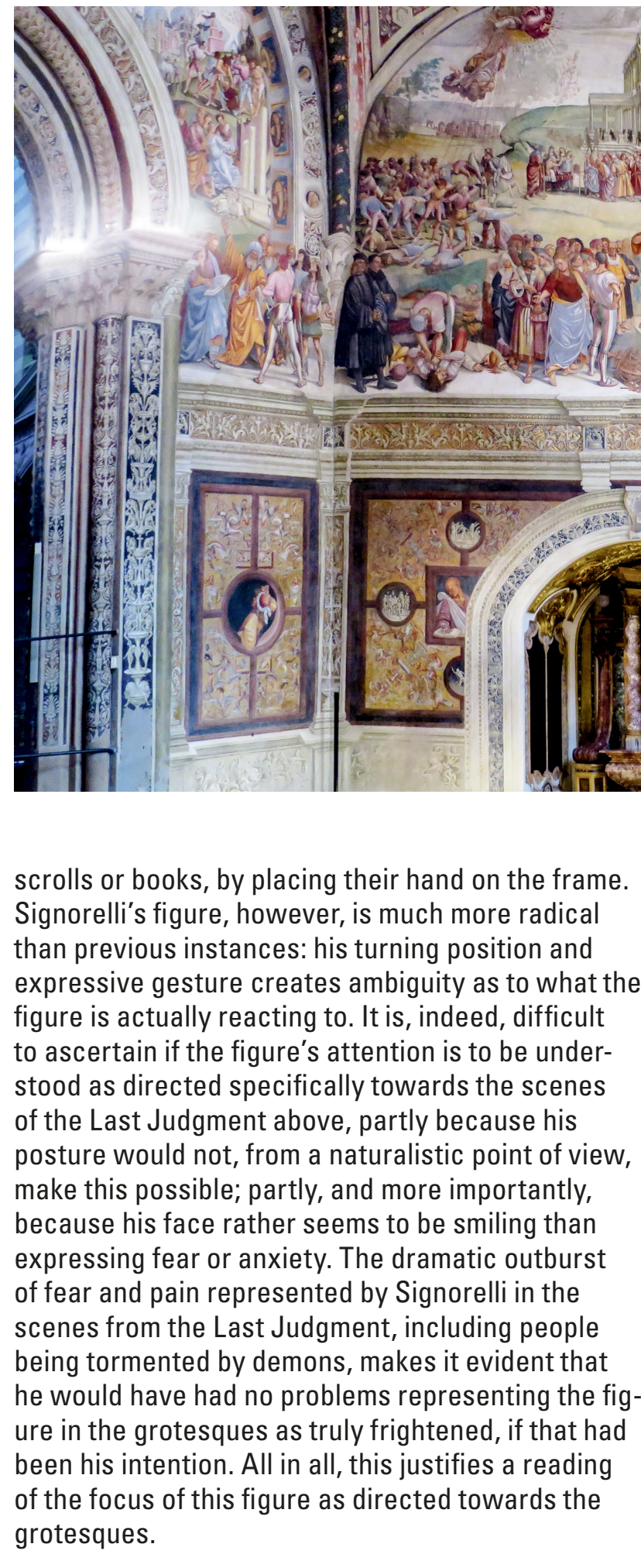

The affect of this figure confronted with the surrounding painting is related to the theoretical observations of the time surrounding the movement of art-how the figures are moved, both physically and psychologically, and how they move or affect the viewer. Leon Battista Alberti, in an often-quoted passage from his treatise On Painting from the mid1430 s, stressed the ability of art to make the dead seem alive:
Figure 3: Luca Signorelli, "The Last Judgement", Cappella Nuova, Cathedral of Orvieto, 1499-1504.

Photo: Author
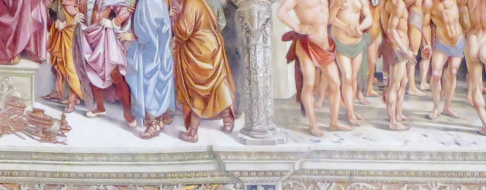

1.
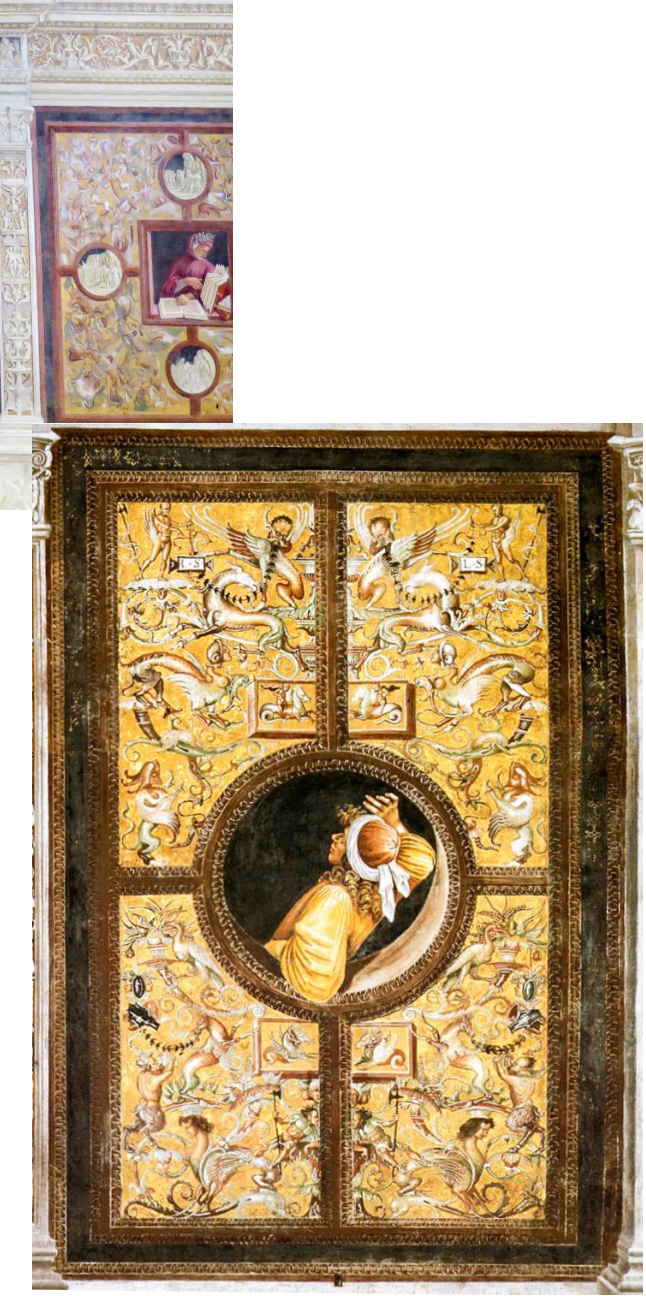

Figure 4: Luca Signorelli, detail of the grotesques, including the artist's monogram "LS" in the upper part), Cappella Nuova, Cathedral of Orvieto, 1499-1504.

Photo: Public domain via Wikiart 
Painting possesses a truly divine power in that not only does it make the absent present ...., but it also represents the dead to the living many centuries later, so that they are recognized by spectators with pleasure and deep admiration for the artist. Plutarch tells us that Cassandrus, one of Alexander's commanders, trembled all over at the sight of a portrait of the deceased Alexander, in which he recognized the majesty of his king. (Alberti, 1972, II. 25, p. $61)^{5}$

In a continuation of this observation-that art affects the viewer both mentally and physicallyAlberti added that the movement of a painted figure will move the viewer:

\begin{abstract}
A "historia" will move spectators when the men painted in the picture outwardly demonstrate their own feelings as clearly as possible. Nature provides ... that we mourn with the mourners, laugh with those who laugh, and grieve with the grief-stricken. Yet these feelings are known from the movements of the body. (Alberti, 1972, II. 41, p. 81)
\end{abstract}

Like many other observations in Alberti's treatise, this notion of art's impact on the viewer was a translation of ancient rhetorical prescriptions to the field of painting. It was particularly based on the Latin rhetorical tradition as represented by Quintilian, Cicero, and others (Spencer, 1957, pp. 26-44; Summers, 1977, pp. 336-361; Baxandall, 1986, pp. 121-139; Vickers, 1988, pp. 340-360). Within this tradition, the human mind was likened to a soft wax tablet, easily imprinted with images by the orator skilled in using efficient, affective strategies. In fact, the theoretical observations in recent decades concerning affective images made by Gottfried Boehm, Horst Bredekamp, and others, echo what was already described in Roman rhetorical theory with terms such as enargeia and evidentia as regards the power of a speech to affect an audience, making mental images appear in their minds (Boehm, 2007, p. 16; Bredekamp, 2010; Vickers, 1988, pp. 321-322); however, with the focus of contemporary theory instead shifting to the interaction taking place between art and the beholder (Castoriadis, 1997, p. 284).

\section{INDECENT, IMAGINATIVE MOVEMENT}

For Alberti, the impact of figural movement was a capacity held by art which should not be exaggerated. He was remarkably cautious towards the enthralling ability of art to imitate life and of art to affect its beholder. While encouraging artists to work specifically to include movement in their painting in order to move the beholder, he also warned artists not to make these movements too excessive. Seen from his point of view, artists committed serious mistakes if:

They represent movements that are too violent, and make visible simultaneously in one and the same figure both chest and buttocks, which is physically impossible and indecent to look at [...quod quidem cum impossibile factu, tum indecentissimum visu est].... In consequence their works are not only devoid of beauty and grace, but are expressions of an extravagant artistic temperament [...sed etiam artificis nimis fervens ingenium exprimunt.] (Alberti, 1972, II. 44, pp. 84-85)

Alberti's critical stance towards the inclusion of such very dramatic movement was more than just a detached observation on a reprehensible artistic practice. It was a matter of great seriousness for him. Note his choice of words: that a figure with violent movements is even indecent, indecentissimus, for the viewer to look at (Hansen, 2000, I, 575-587).

As David Summers convincingly argues in his work, the problem for Alberti was that a dramatic movement was synonymous with the artistic imagination becoming too explicit (Summers, 1977, pp. 339-344). In other words, Alberti was skeptical of the artistic imagination becoming a theme in its own right, and that the twisting of a figure-i.e., the contrapposto - was synonymous with a representation of the artist's imagination and creative power.

This cautious attitude toward movement underwent a radical development from the fifteenth to the sixteenth century. While restrictions in movement are distinctive for art throughout most of the fifteenth century, contrappostos which were as imaginative and dramatic as possible were not only accepted, but highly appreciated in the sixteenth century (Summers, 1977, pp. 343-358). The conventional, balanced, frontal pose present in fifteenth-century art was replaced by figure serpentinate, spiraling bodies, sometimes inverted to a degree that would make their feet and faces point in opposite directions - exactly what Alberti had disapproved of. Later in the sixteenth century, the eloquent art theorist Gian Paolo Lomazzo actually emphasized the figura serpentinata as the most attractive movement in a figure because it embodied the furia or poetic imagination understood as a movement of the artists (Shearman, 1967, pp. 81-91; Summers, 1972, p. 271). 


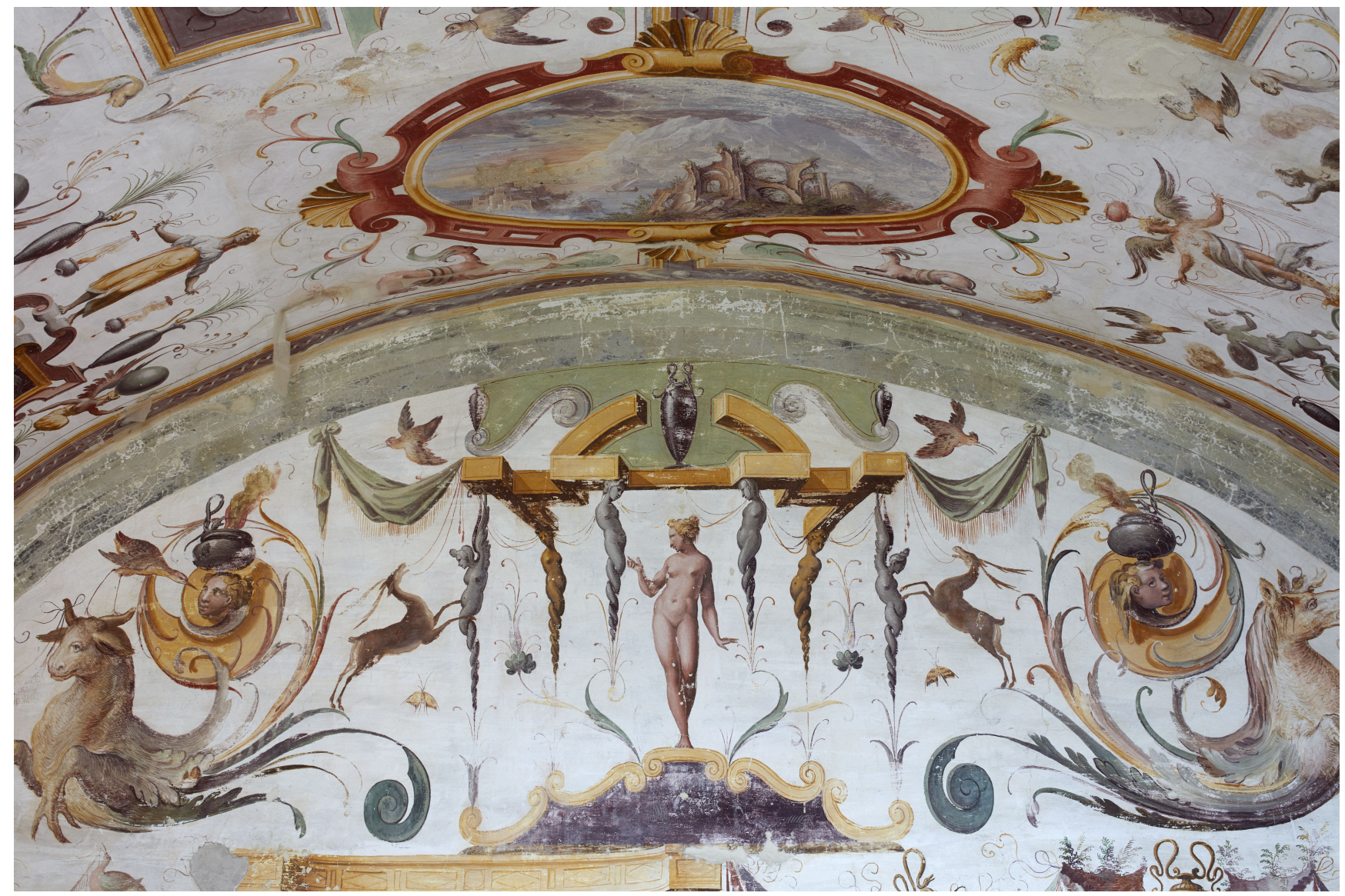

Figure 5: Serpentine figures within the grotesques of Cesare Baglione and his circle, Sala dei Paesaggi, Castello di Torrechiara, c. 1590. With permission from the Ministero per $\mathrm{i}$ Beni e Attività Culturali - Polo Museale dell'Emilia Romagna.

Photo: Pernille Klemp

\section{GROTESOUE CONTRAPPOSTOS}

Interestingly, Lomazzo also found this movement (both in its literal and its metaphorical sense) manifest in successful grotesques. ${ }^{7}$ In line with this, sixteenth-century grotesques abound with such serpentine figures (Figure 5). In Orvieto, Signorelli's fresco seems to bridge the old paradigm on movement in art and the new, or modern one, developing at the time. His implication of the field of grotesques striking his ancient poet with surprise aligns with the involvement in the affect of images, in terms of how images move both physically and emotionally.

Sixteenth-century grotesques are composed of elements from nature juxtaposed by constellations unknown in our physical reality. ${ }^{8}$ As a composition of opposing elements, the grotesques may be characterized as a kind of contrapposto, a turning and even a perversion of one figure into another in an on-going metamorphosis of long sequences of hybrid monstrosity. I use the word perversion here in the literal sense as an excessive twisting of the figure, but the word's metaphorical connotations with something deviant are just as relevant to the understanding of the way in which such figures were perceived at the time. It corresponds to Alberti's warning against too drastic (and, thus, indecent) contrappostos. That movement was not just an innocent way of composing a figure but a highly-charged strategy in art is, moreover, consistent with Vasari's use of a strong word such as "terribile" about grotesques-for instance, the ones painted by Giovanni da Udine (Figure 2; Vasari, 1966$97, \mathrm{~V}$, Testo, p. 452). To see them merely as trivial, decorative paintings would be far from the way they were perceived back in the sixteenth century. Vasari's choice of words points to the movement and hybrid ambiguity of the grotesques, and to their very inventiveness as affecting the viewer. For Vasari, the word "terribilità" - it is worth remembering - was also used in descriptions of the highest ideal of an artist, namely, Michelangelo, whom Vasari repeatedly praised for this, referring to the terrifying qualities and grand affective power of his art (Vasari, 1966-97, VI, Testo, pp. 3-141). 


\section{GROTESQUE ARTISTS}

In writings on art in the sixteenth century by Vasari and others, artists specializing in grotesques were associated with peculiar behavior, strange psychology, melancholia, and deviant sexuality-in short, all sorts of deformities of body and mind. The grotesques affected or exerted an attraction on artists with such dispositions. To a certain extent, this kind of painting was inspired by ancient frescoes found in Roman ruins - particularly, the Domus Aurea (c. A.D. 64-68), i.e., the Golden Palace of the Emperor Nero. These buried ruins were called grottoes, leading to the term grotesque to designate the frescoes found there (Vasari, 1996, II, p. 488; I, p. 926; Cellini 2002, I, 31, p. 53; Doni and Paleotti in Barocchi, 1971-77, I, p. 584; III, p. 2640; Dacos, 1969, pp. 3-4). The mythic significance of the grotto included both death and birth, as grottoes represented feminine, life-giving forces, the womb of the earth, but were also related to burial (Pieper, 1987; Bredekamp, 1981; Wamberg, 2009, II, pp. 247-363; Connelly, 2012, pp. 1-4). Moreover, the ancient Roman ruins were seen as corpses or skeletons along the lines of the metaphorical understanding (prevalent at the time) of buildings as a human body (Hansen, 1996, pp. 100108). Unsurprisingly, the ancient frescoes were understood to be somewhat disturbing or dangerous, and it was also debated whether they had originally belonged to rooms below ground, evidently connecting them to the Underworld (Ligorio in Dacos, 1969, pp. 161-162; Paleotti in Barocchi, 1971-77, III, pp. 2640-2653).

These gloomy, chthonic associations are present in Vasari's biography of Morto da Feltre, whom Vasari praised for his bizarre grotesques. Typically, Vasari characterized this enigmatic artist as a melancholic; and, all in all, the biography exposes him as a rather strange, deviant personality (Vasari, 1996, I, pp. 924926). ${ }^{9}$ According to Vasari, Morto was as astratto, i.e., abstracted or far-fetched, in his life as he was "in his brains and in his innovative grotesques." ${ }^{10}$ Vasari also relates that, at some point, the restless Morto was bored with the orderly Florence, which for Vasari himself, needless to say, represented a paramount cultural civilization and was an unchallenged center of ideal, conceptual, clear and well-defined art. Morto therefore moved on to Venice, "attracted by the sensuous pleasures and delights that he found there", hinting at Venice's tarnished reputation at the time as a place of sensuous lust and unrestricted sexuality (Vasari, 1996, I, p. 926). Morto was also associated with death through his name. This is underscored by Vasari, who tells that he died in battle and "was left dead on the field, even as he had always been in name..." (Vasari, 1996, I, p. 926). Morto's name corresponded with his fascination of the grotesque, with the bizarre and imaginative painting found in the Underworld, in the corpse of ancient ruins, in the body of Mother Earth.

Another of the artists first associated with the study of the ancient frescoes was Pinturicchio, one of many whose name features in graffiti in the Domus Aurea (Dacos, 1969, pp. 140, 156, Fig. 55). $\mathrm{He}$ is represented in an obscene verse: "OMGNI POLTRO GHUASTAT / PINTORICHIO SODOMITO," which more or less translates to "Pinturicchio the Sodomite ruins all young men."

\section{GROTESQUES, SIGNATURES, SELF-PORTRAITS}

As figures of motion and, thus, somewhat alarming and perverted, the grotesques were equated with the deviant personalities of artists. Just as movement in art was associated with movement in the artistic imagination, so also did the affective, hybrid, monstrous contrappostos of the grotesques turn them into a kind of self-portraiture of the artist. This association of the grotesques with the artists is corroborated by the poem of the so-called Anónimo Milanese. Written around 1500 and including one of the very early mentions of the term grottesche, it is a sensuous description of the early field studies of the cavernous, soil-filled rooms of the Domus Aurea:

\section{We crawl into them [the "grottoes" or ruins] on our bellies \\ with bread and ham, apples and wine, to behave more peculiar than the grotesques. \\ Our guide is Mastro Pinzino \\ who makes us rub our faces and eyes in the dirt \\ indeed, each of us looks like a chimney sweep.}

He brings us to see toads, frogs, owls, barn owls and bats

while we break our backs on our knees. ${ }^{11}$

The stanzas quoted are only part of a long enumeration of sights in Rome. But the passage is remarkable because it describes the artists whom are visiting the "grottoes" to study the ancient frescoes as being transformed into peculiar creatures through their investigation, affected by or becoming like the motifs they study. ${ }^{12}$ The narrow, cavernous spaces force the artists to crawl awkwardly on all fours ("breaking their backs on their knees") and get dirty. Thus, they themselves are turned into deformed, monstrous figures - a metamorphosis of humans into animals-much like the grotesques. 
Along with their disquieting aspects, the grotesques constituted a field in which figuration originated, the field framing or defining (from Latin fines, i.e., limit, border) the central image. Parallel to this, the artists' self-portraits and signatures were typically situated in the margins of the work of art. Signorelli, for instance, included his initials in only one place in the San Brizio Chapel: In the field of grotesques that surrounds the figure acting with affect. For Signorelli this was apparently the appropriate locus for his " $L S$ ", the signature indicating the origin of the work (Figure 4).

In an extraordinary painting, one of the earliestalmost-autonomous self-portraits in the history of art, Pinturicchio framed his image within the image of an Annunciation by painted pilasters with grotesques (Figure 6). He even emphasized the significance of the grotesque as a figuration of artistic imagination by the inclusion of the date 1501 ("MCCCCCI") on the pilaster to the left of his portrait-thus, situating the origin of the work here.

The artist Giovanni Antonio Bazzi, who went under the noteworthy nickname Sodoma, was also a protagonist in the early history of grotesques. He included his self-portrait in his frescoes at the cloister of Monte Oliveto Maggiore (1505-08; Figure 7). In his "Life of Sodoma", Vasari criticized Sodoma's lack of virtue and described his conduct with the words "eccentric and beastly," bestiale in Italian (Vasari, 1966-97, V, Testo, p. 381). In Vasari's narrative, Sodoma was surrounded not only by very young male lovers (the reason for his nickname) but also with all sorts of strange animals, like the unorthodox pets depicted in the Monte Oliveto self-portrait (two badgers and a talking (!) raven, thereby drawing an analogy between the circumstances of his personal life-what Vasari called the bestiality of his behavior-and the licentiousness of his art (Vasari, 196697, V, Testo, pp. 381-390). In addition to the painted pilasters with grotesques, framing each scene in the cloister, Sodoma included an extra pilaster with grotesques next to his self-portrait, within the narrative of the figural composition. In a strategy parallel to Pinturicchio's he thus represented himself framed by grotesques as a kind of trademark for his art and his inventive imagination. The prominence of Sodoma in the center of the fresco, represented together with his strange pets and the grotesques, may seem surprising. The series of frescoes were otherwise supposed to illustrate the life and deeds of Saint Benedict. The displacement of the saint to a secondary position on the left of the fresco, is, however, in line with a general tendency of the sixteenth century: the frame in its broadest sense, as all kinds of marginal figurations, including grotesques and self-portraits of the artists, began to expel and replace the centrality of the main, narrative work or content (Derrida, 1987, pp. 15-147).

\section{BETWEEN SPACES, BETWEEN PARADIGMS}

Around 1500, the perception of grotesques seems to be oscillating between an extraordinary fascination and a remarkable fear of movement-an oscillation between, on one hand, a new self-confidence on the part of the artist and an appreciation of his imaginative power, and, on the other hand, a nagging concern about blasphemy by interfering with a creative field reserved for God: in simulating life itself. ${ }^{13}$ Signorelli's grotesques are generated from the old attitude to movement in art as terrifying. But there are limits to the terror. The figure depicted as responding to the surrounding frescoes does not appear to be really frightened by them. Moreover, and not least, the figure is not alive. The beholder would not mistake this, and rather appreciate that Signorelli's representation is art, not life. The absorption with the affective potential of the imagery is remarkable. The representation of the reaction of the figure, observing the painting of which he is part, is, quite literally, a self-aware image. ${ }^{14}$ Signorelli exhibits the zone of transition between the pictorial space and the space of the viewer, as it had been done in painting for at least a couple of centuries, although not quite as radically (Sandström, 1963; Shearman, 1992). This breach of the boundaries between the image and the spectator would become a leitmotif in the art of

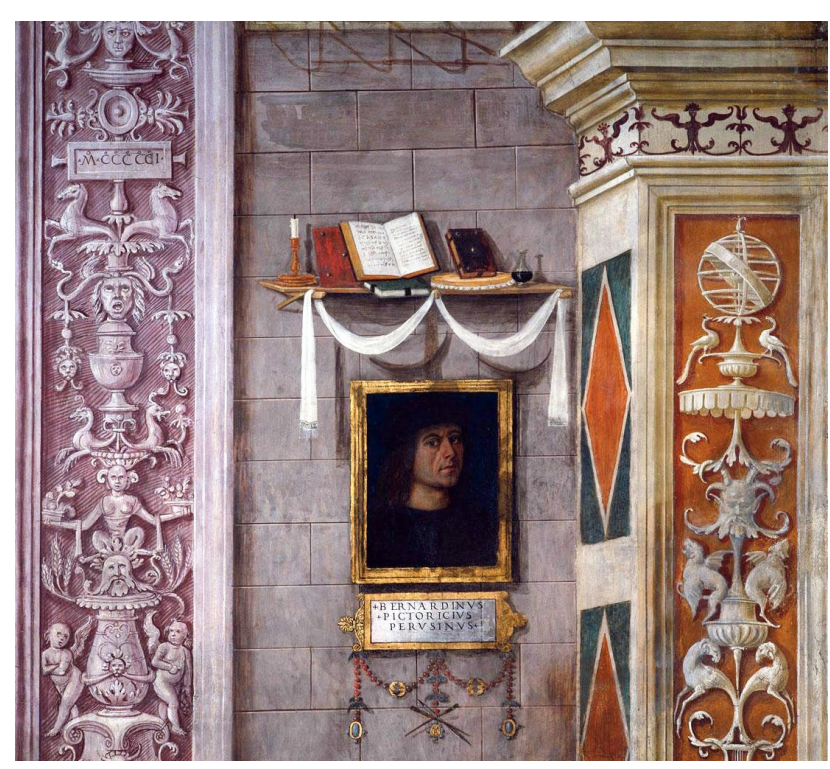

Figure 6: Pinturicchio, detail with self-portrait and pilasters with grotesques and the date "MCCCCCl" (1501) within his "Annunciation", Cappella Baglione, Collegiata Santa Maria Maggiore, Spello.

Photo: Public domain via Wikimedia Commons 


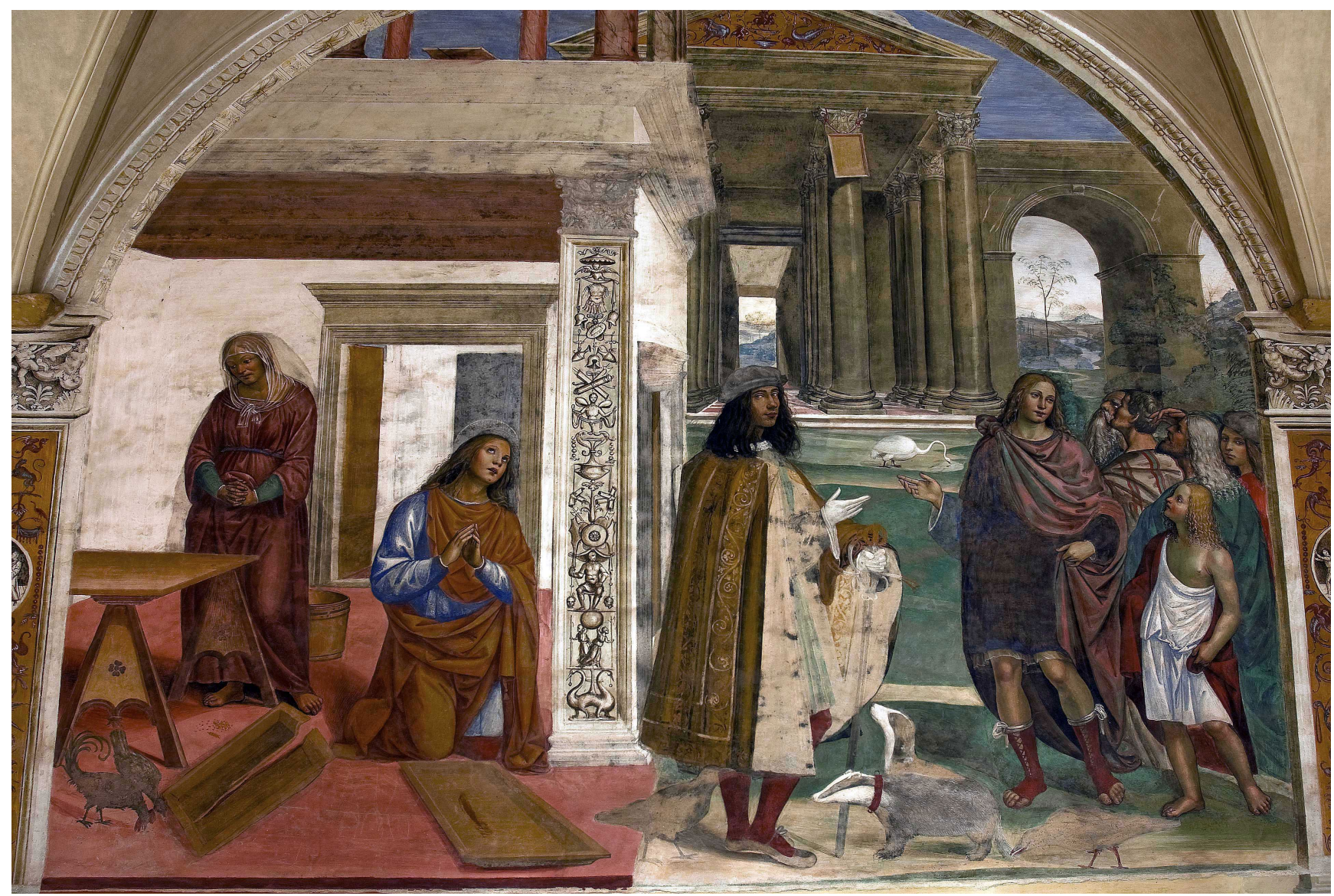

Figure 7: Sodoma (Giovanni Antonio Bazzi), self-portrait with his two badgers and his tame, talking raven. He is standing next to a pilaster with grotesques and dominates the center of the scene "Benedict Repairs a Broken Colander through Prayer". The cloister of the Abbey of Monte Oliveto Maggiore, 1505-08.

Photo: Public domain via Wikipedia

the sixteenth century, just as it became a decisive constituent of the grotesque (Connelly, 2012, pp. 8-13; Kristeva, 1982, p. 4).

Signorelli engaged directly with the equation of artistic imagination and painting to the movements and perversions of images and their affective potential by means of the grotesques, synonymous with strange and bizarre art made by strange and eccentric artistic personalities.

But, apparently, Signorelli also marked a distance to the conventional preoccupation formulated by Alberti about moving images and artistic self-representation that is too explicit. ${ }^{15} \mathrm{His}$ painting embodies a fascinating ambivalence: on one hand, he seems to acknowledge artistic imagination and the affective potential of the work of art; on the other hand, he points to the fact that the image is not moving, that it is not alive-in other words, he points to the image as art.
The grotesques by Signorelli and others around 1500 exemplify the period's translation of an antique and medieval visual culture into a contemporary version in which movement and metamorphosis were invested with an unprecedented importance. The reflexiveness of the grotesques is part of this innovation: They refer to their own genesis as an inventive imagery created by the artist. Turning the relation between life-like movement and artificiality into a theme, they represent a shift in paradigms.

According to conventional notions of art, the painter imitated Nature by repeating "her" generative force, Nature's capability of creation and growth. But according to modern notions, gradually developing throughout the sixteenth century, nature was no longer perceived as an active force. Thus, the creation of images shifted from a process of extracting something already present in Nature to a process taking place in the imagination of the artist. With their investigation into the origin, appearance, and movement of images, the grotesques points 
toward this modern view of artistic genesis. The sixteenth-century fascination for the grotesque seems to reflect that the creative process itself, as well as distance between the artist and his workeven an ironical distance -were gradually becoming main qualities of artistic production. It is within this distance, the space in-between the artwork, the artist, and the beholder, that the affect of images take place.

\section{NOTES}

1. See, e.g., L.B. Alberti's treatise On Painting, especially Book II (1972, pp. 60-93); Vasari's Lives, passim, and, e.g., "Preface to the Third Part" (1996, I, pp. 617-623); Close (1969).

2. Major surveys of the field include Kayser (1957); Piel (1962); Dacos (1969); Barasch (1971); Harpham (1982); Chastel (1988); Morel (1997); Connelly (2012); Zamperini (2007).

3. For an important study of movement and metamorphosis from around 1100 and after, see Bynum (2001); for a general view of the period in which movement is understood as a key feature, see Koyré (1957, pp. 5-57), or his article on "Galileo and the Scientific Revolution" (1943), published in English in 1968, pp. 1-15; for the extraordinary interest in Pythagorean ideas about, e.g., the transmutation of the elements around 1500, see Heninger (1974) and Joost-Gauguier (2009).

4. The identification of this figure is uncertain. The conventional suggestion, "Empedocles", is not substantially corroborated; see James (2003, p. 90).

5. Alberti concludes that "[t]he virtues of painting, therefore, are that its masters see their works admired and feel themselves to be almost like the Creator [deo]." (Alberti, 1972, II.26, p. 61).

6. And as an extension of this: "The painter, therefore, must know all about the movements of the body, which I believe he must take from Nature with great skill. It is extremely difficult to vary the movements of the body in accordance with the almost infinite movements of the heart." (Alberti, 1972, II.42, p. 81). Moreover, the painter will obtain praise "if his painting holds and charms the eyes and minds of spectators" ["dum eius pictura oculos et animos spectantium tenebit atque movebit."] (Alberti, 1972, III.52, p. 95).

7. Summers (1981, p. 62) quotes Lomazzo on the grotesques: "There are painters who succeed in figures, but who win no praise in grotteschi, 'because in the invention of grotteschi more than in anything else there runs a certain furor and a natural bizzaria, and being without it they are unable to make anything, for all their art."'; cf. Lomazzo in Barocchi (Ed.) (1971-77, III, p. 2695).

8. Cf. Marsilio Ficino's eloquent and influential observations on art, nature, and imagination from his Theologia platonica, XIII.iii: "human arts produce by themselves whatever nature itself produces, as if we were not the slaves, but the rivals of nature.... Thus man imitates all the works of the divine nature, and perfects, corrects and improves the works of the lower nature. Therefore the power of man is almost similar to that of the divine nature, for man acts in this way through himself. Through this own wit and art he governs himself, without being bound by any limits of corporeal nature; and he imitates all the works of the higher nature." In Kristeller (1944, p. 233).

9. Dacos (1969, pp. 140,150,159) convincingly suggests that two inscriptions in the Domus Aurea, "ANTONI DA FELTRO" and "Antonio Morto", may stand for the artist Vasari calls Morto da Feltre, although it cannot be proved. It is worth noting that Andrea di Cosimo Feltrini with whom Morto worked, according to Vasari, 1996, I, p. 925, also left his signature in the same room (the Criptoportico of the Domus Aurea) as "ANTONI DA FELTRO"; Barolsky (1991, pp. 58-60) has suggested that this enigmatic artist never existed but was a kind of creative invention by Vasari (without discussing Dacos's observations on the graffiti). However, Vasari's relatively detailed information regarding works executed by Morto da Feltre (1996, I, p. 925) points in the direction of the specific, existing artist. It has been suggested that he may have been Lorenzo Luzzo of Feltre in northern Italy (Ericani, 1994, 99-128), but the signature in the Domus Aurea would, then, still need clarification.

10. “Morto, pittore da Feltre, il quale fu astratto nella vita come era nel cervello e nelle novità nelle grottesche ch'egli faceva...", Vasari (1966-97, IV, Testo, p. 517).

11. Fienga (1971, pp. 55-56); Govi (1876, p. 17): “Hor son spelonche ruinate grotte .../Andian per terra con nostre ventresche / con pane con presutto poma e vino / per esser piu bizzarri alle grottesche / El nostro guidarel mastro pinzino / che ben ci fa abottare el viso elochio / parendo inver ciaschun spaza camino / Et facci traveder botte ranochi / civette e barbaianni e nottiline / rompendoci la schiena cho ginochi".

12. The eating and drinking (bread, ham, apples, and wine) point to the mouth and to digestion as crucial themes within the grotesques: The body openings as the zones of passage between the body and its surroundings, i.e., the body's processes of transformation as an 
essential condition of life, cf. Bakhtin (1968, pp. 18-40); allusions to a spiritual transformation by associations to the Eucharist (bread and wine) are possible, too.

13. Cf. the statement by Alberti on the divine powers of art to "create" life, quoted above, and the passage on the same subject by Ficino, quoted in note 8 . For an important account of the relation between art and life in the sixteenth century, see Campbell (2002, pp. 596-620); on the simulacrum as constituent element in Western imagination, see Stoichita (2008, passim, p. 202).

14. On the self-aware image in sixteenth-century art, see Stoichita (1997).

15. The locus classicus regarding the limits of artistic license is, of course, found in the poetics of Horace (1970, pp. 450-451).

\section{REFERENCES}

Alberti, Leon Battista. (1972). On painting and on sculpture (C. Grayson, Ed. \& Trans.). London: Phaidon.

Bakhtin, Mikhail. (1968). Rabelais and his world, (Helene Iswolsky, Trans.). Cambridge, Mass.: The MIT Press.

Barasch, Frances K. (1971). The grotesque: a study in meanings, (De proprietatibus litterarum. Series maior vol. 20). The Hague and Paris: Mouton.

Barocchi, Paola. (Ed.). (1971-77). Scritti d'arte del cinquecento. Milan \& Naples: Riccardo Ricciardi Editore.

Barolsky, Paul. (1991). Why Mona Lisa smiles and other tales by Vasari. University Park, Pennsylvania: Pennsylvania State University Press.

Baxandall, Michael. (1986). Giotto and the orators: humanist observers of painting in Italy and the discovery of pictorial composition 1350-1450. 0xford: Clarendon Press. First ed., 1971.

Boehm, Gottfried. (2007). Wie Bilder Sinn erzeugen: Die Macht des Zeigens. Berlin: Berlin University Press.

Bredekamp, Horst. (1981). Die Erde als Lebewesen. Kritische Berichte, 9(4-5), 5-37.

Bredekamp, Horst. (2010). Theorie des Bildakts (Frankfurter Adorno-Vorlesungen 2007). Berlin: Suhrkamp.

Bynum, Caroline Walker. (2001). Metamorphosis and identity. New York: Zone Books.

Campbell, Stephen J. (2002). 'Fare una cosa morta parer viva': Michelangelo, Rosso, and the (un)divinity of art. Art Bulletin, 84(4), 596-620.

Castoriadis, Cornelius. (1997). Merleau-Ponty and the weight of the ontological tradition. In C. Castoriadis, World in fragments: writings on politics, society, psychoanalysis, and the imagination. (D. Ames Curtis, Ed. \& Trans.). Stanford: Stanford University Press, 273-310.

Cellini, Benvenuto. (2002). My life. (J. Conaway Bondanella \& P. Bondanella, Trans., Intr. \& Not.). Oxford: Oxford University Press.
Chastel, André. (1988). La grottesque. Paris: Le Promeneur.

Close, A. J. (1969). Commonplace theories of art and nature in classical antiquity and in the renaissance. Journal of the History of Ideas, 30(4), 467-486.

Connelly, Frances S. (2012). The grotesque in western art and culture: the image at play.Cambridge: Cambridge University Press.

Dacos, Nicole. (1969). La découverte de la Domus Aurea et la formation des grotesques à la Renaissance. London: The Warburg Institute.

Dacos, Nicole \& Furlan, Caterina. (1987). Giovanni da Udine 14871561. Udine: Casamassima.

Derrida, Jacques. (1987). The parergon [1978]. In J. Derrida, The truth in painting (G. Bennington \& I. McLeod, Trans.). Chicago and London: University of Chicago Press, 15-147.

Ericani, Giuliana. (1994). Lorenzo Luzzo, Pietro de Marascalchi ed il cinquecento feltrino. In G. Ericani (Ed.), Pietro de marascalchi: restauri studi e proposte per il cinquecento feltrino. Treviso: Canova, 99-157.

Fienga, Doris Diana. (1971). The Antiquarie prospetiche romane composte per prospectivo melanese depictore: a document for the study of the relationship between Bramante and Leonardo da Vinci. Ann Arbor, Michigan: University Microfilms International.

Govi, Gilberto (1876). Intorno a un opuscolo rarissimo della fine del secolo XV intitolato Antiquarie prospettiche romane composte per prospettivo milanese dipintore. Roma: Salviucci.

Hansen, Maria Fabricius. (1996). Representing the past: the concept and study of antique architecture in 15th-century Italy. Analecta Romana Instituti Danici, 36, 83-116.

Hansen, Maria Fabricius. (2000). La fureur du grotesque: Alberti, Mantegna et l'autoreprésentation artistique. In Leon Battista Alberti: actes du congrès international de Paris 1995, I-II. (F. Furlan, Ed.). Paris: Vrin, I, 575-587.

Harpham, Geoffrey Galt. (1982). On the grotesque: strategies of contradiction in art and literature. Princeton New Jersey: Princeton University Press.

Heninger, S.K., Jr. (1974). Touches of sweet harmony: Pythagorean cosmology and Renaissance poetics. San Marino, California: The Huntington Library.

Horace. (1970). Satires, epistles and ars poetica (H. Rushton Fairclough, Trans.). Cambridge, Mass. \& London: Harvard University Press.

James, Sara Nair. (2003). Signorelli and Fra Angelico at Orvieto. Aldershot: Ashgate.

Joost-Gauguier, Christiane L. (2009). Pythagoras and Renaissance Europe: finding heaven. Cambridge: Cambridge University Press.

Kayser, Wolfgang. (1957). Das Groteske. Seine Gestaltung in Malerei und Dichtung. Oldenburg \& Hamburg: Gerhard Stalling.

Koyré, Alexandre. (1957). From the closed world to the infinite universe. Baltimore: Johns Hopkins Press.

Koyré, Alexandre. (1968). Metaphysics and measurement: essays in scientific revolution. London: Chapman \& Hall. 
Kristeller, Paul O. (1944). Ficino and Pomponazzi on the place of man in universe. Journal of the History of Ideas, 5, 227-242.

Kristeva, Julia. (1982). Powers of horror: an essay on abjection. (Leon S. Roudiez, Trans.). New York: Columbia University Press.

Morel, Philippe. (1997). Les grotesques: les figures de l'imaginaire dans la peinture italienne de la fin de la Renaissance. Paris: Flammarion.

Piel, Friedrich. (1962). Die Ornament-Grotteske in der italienischen Renaissance: Zu ihrer kategorialen Struktur und Entstehung. Berlin: De Gruyter.

Pieper, Jan. (1987). Das Labyrintische: Über die Idee des Verborgenen, Rätselhaften, Schwierigen in der Geschichte der Architektur. Basel: Vieweg.

Sandström, Sven. (1963). Levels of unreality: studies in the structure and construction in Italian mural painting during the Renaissance (Figura: Uppsala Studies in the History of Art, New Series 4). Uppsala: Almqvist \& Wiksells Boktryckeri.

Schulz, J. (1962). Pinturicchio and the revival of antiquity. Journal of the Warburg and Courtauld Institutes, 25(1-2), $35-55$.

Shearman, John. (1967). Mannerism. Harmondsworth: Penguin.

Shearman, John. (1992). Only connect...: art and the spectator in the Italian Renaissance. (The A.W. Mellon Lectures in the Fine Arts, 1988) (Bollingen series, XXXV, 37). Princeton, New Jersey: Princeton University Press.

Spencer, John R. (1957). Ut rhetorica picture: a study in quattrocento theory of painting. Journal of the Warburg and Courtauld Institutes, 20, 1957, 26-44.

Stoichita, Victor I. (1997). The self-aware image: an insight into early modern meta-painting, (Anne-Marie Glasheen, Trans.). Cambridge: Cambridge University Press.

Stoichita, Victor I. (2008). The Pygmalion effect: from Ovid to Hitchcock, (Alison Anderson, Trans.). Chicago \& London: The University of Chicago Press.

Summers, David. (1972). Maniera and movement: the figura serpentinata. Art Quarterly, 35, 269-301.

Summers, David. (1977). Contrapposto: style and meaning in Renaissance art. Art Bulletin, 59(3), 336-361.

Summers, David. (1981). Michelangelo and the language of art Princeton, New Jersey: Princeton University Press.

Vasari, Giorgio. (1966-97). Le Vite de' più eccellenti pittori, scultori e architettori nelle redazioni del 1550 e 1568. Rosanna Bettarini \& Paola Barocchi (Eds.). Firenze: Sansoni.

Vasari, Giorgio. (1996). Lives of the painters, sculptors and architects (Gaston du C. de Vere, Trans. \& David Ekserdjian, Intr.), I-II. New York \& Toronto: Everyman's Library.

Vickers, Brian. (1988). In defence of rhetoric. Oxford: Clarendon Press.

Wamberg, Jacob. (2009). Landscape as world picture: tracing cultural evolution in images, I-II. Aarhus: Aarhus University Press.

Zamperini, Alessandra. (2007). Le Grottesche: I/ sogno della pitura nella decorazione parietale. Verona: Arsenale.
CORRESPONDENCE

Maria Fabricius Hansen

Department of Arts and Cultural Studies

University of Copenhagen

Karen Blixensvej 1

2300 Copenhagen $S$

Denmark

Phone: +45 40876828

E-mail:mfhansen@hum.ku.dk

Published online, 2017

ISSN 1749-3463 print/ISSN 1749-3471

https://doi.org/10.14434/artifact.v4i1.13122

(C) 2017 Artifact 